\title{
Illegal, Unreported and Unregulated Fishing Control in the Exclusive Economic Zone: a Brief Appraisal of Regulatory Deficits and Accountability Strategies
}

Mercedes Rosello

\section{Abstract}

The conservation of fish stocks in the world's exclusive economic zones (EEZs), which collectively harbour the vast majority of marine-living resources, is the primary responsibility of coastal States. As the effects of failures by coastal States to protect those stocks from the impacts of illegal, unreported and unregulated (IUU) fishing may extend beyond domestic boundaries, this paper questions whether and how coastal States may be made accountable in respect of their regulatory deficits. With the proliferation of non-legal conduct rules to guide the regulatory role of States and their agencies, non-judicial mechanisms have the potential to foster coastal State stewardship of domestic fisheries. Outlining a number of international, transnational and domestic approaches, this paper gives consideration to the opportunities and limitations they present in order to strengthen coastal State accountability for IUU fishing control deficits.

KEY WORDS:

IUU fishing, exclusive economic zone, regulation, conservation 


\section{Introduction}

Illegal, unreported and unregulated (IUU) fishing is a frequently reliedupon expression in fisheries policy and management circles to refer to operations involving the harvesting of marine fish stocks carried out in ways that either contravene or circumvent domestic or international fisheries conservation and management laws and/or the conservation and management rules of certain international organisations. Due to its vast environmental and human costs, IUU fishing has gained visibility in recent years, making headlines and being featured in international security agendas (see Bueger 2015). Much attention has rightly been paid to the complex issues raised by IUU fishing in the high seas and associated issues of flag State responsibility, yet IUU fishing activities in the Exclusive Economic Zone (EEZ) and the responsibilities of coastal States to address it merit just as much attention.

As specified in the 1982 United Nations Convention on the Law of the Sea (LOSC), the EEZ of a coastal State is the area beyond and adjacent to the territorial sea (LOSC: Art. 55), measuring up to 200 nautical miles from the baseline from which the territorial sea is measured (ibid.). Fish stocks that do not occur outside this area can be accessed by domestic fleets but also in some circumstances by the fleets of foreign States. These fleets generally carry out their fishing activities constrained by domestic laws and, where applicable, by the terms of bilateral access agreements signed between the State where the fishing vessel is registered, or flag State, and the coastal States, or private agreements signed directly between coastal States and vessel owners or operators. Where these fleets act in ways that are detrimental to conservation, it can be difficult to determine in practice whether and to what extent those activities constitute IUU fishing, who is responsible for their conduct and what consequences should follow.

This article introduces the term IUU fishing and highlights its relevance to the activities of fleets operating in the EEZ for non-transboundary stock. It also explores the responsibility of the coastal State in respect of these operations by reference to a recent advisory opinion by the International Tribunal for the Law of the Sea (ITLOS). Highlighting that the coastal State bears the primary, though not exclusive, responsibility for the IUU fishing 
operations of vessels inside the EEZ, the article argues that opportunities to make the coastal State accountable for shortcomings in its conservation and management obligations, which include those in respect of IUU control, are insufficient at the international level. Yet, although deficient and underdeveloped, accountability mechanisms are not completely absent, particularly when non-judicial and domestic options are taken into consideration.

\section{IUU Fishing: A Complex Issue Empirically and Legally}

The first global document to specify the scope of IUU fishing was the 2001 International Plan of Action to Prevent, Deter and Eliminate Illegal, Unreported and Unregulated Fishing (IPOA IUU, or IPOA) (FAO 2001), which is a non-binding toolbox for States seeking to combat IUU fishing. The IPOA's description of IUU fishing has now been consolidated in the corpus of international law.' Rather than enabling binary 'legal versus illegal' assessments of conduct, the description is arguably better suited to assisting regulators in addressing fishing practices perceived as being included in one or more of the following three categories, as set out in paragraph 3 of the IPOA:

3.1 Illegal fishing refers to activities:

3.1.1 conducted by national or foreign vessels in waters under the jurisdiction of a State, without the permission of that State, or in contravention of its laws and regulations;

3.1.2 conducted by vessels flying the flag of States that are parties to a relevant regional fisheries management organization but operate in contravention of the conservation and management measures adopted by that organization and by which the States are bound, or relevant provisions of the applicable international law; or 
3.1.3 in violation of national laws or international obligations, including those undertaken by cooperating States to a relevant regional fisheries management organization.

For the purposes of coastal State regulation of fishing activities in the EEZ, paragraph 3.1.1 is a straightforward assertion of the need for vessels to comply with the domestic law of the coastal State. Paragraphs 3.1.2 and 3.1.3 imply the obligation of States to create at the domestic level binding laws for vessels. In the waters under the jurisdiction of coastal States, illegal fishing will occur as determined by such domestic legislation (Palma et al. 2010: 30), which will in turn be conditioned by existing international obligations. If domestic laws do not exist or are inadequate and, as a consequence, vessels are able to operate with impunity in ways that undermine regional and international conservation rules applicable to the coastal State, this may be indicative of underlying deficits in that State's observance of international law.

3.2 Unreported fishing refers to fishing activities:

3.2.1 which have not been reported, or have been misreported, to the relevant national authority, in contravention of national laws and regulations; or

\begin{abstract}
3.2.2 undertaken in the area of competence of a relevant regional fisheries management organization which have not been reported or have been misreported, in contravention of the reporting procedures of that organization.
\end{abstract}

The second perspective, unreported fishing, refers first to activities by vessels that contravene the specific domestic laws that regulate the reporting of fishing activity or catch. In this sense, unreported fishing is simply a sub-category of illegal fishing. Like paragraph 3.1.2, paragraph 3.2.2 refers to activities that contravene the secondary rules stemming from international organisations collectively known as regional fishery management organisations (RFMOs). ${ }^{2}$ Most RFMOs are generally engaged in the management and conservation of straddling or highly migratory

2 IPOA IUU Paragraphs 3.2.1 and 3.2.2. 
species occurring in whole or in part in the high seas, but not domestic stock occurring exclusively in the EEZ. The requirement in paragraph 3.2 of the IPOA for a rule contravention implies that vessels flagged to States that have not agreed to abide by the rules of the RFMOs are excluded from this prong of the description.

3.3 Unregulated fishing refers to fishing activities:

3.3.1 in the area of application of a relevant regional fisheries management organization that are conducted by vessels without nationality, or by those flying the flag of a State not party to that organization, or by a fishing entity, in a manner that is not consistent with or contravenes the conservation and management measures of that organization; or

3.3.2 in areas or for fish stocks in relation to which there are no applicable conservation or management measures and where such fishing activities are conducted in a manner inconsistent with State responsibilities for the conservation of living marine resources under international law.

3.4 Notwithstanding paragraph 3.3, certain unregulated fishing may take place in a manner which is not in violation of applicable international law, and may not require the application of measures envisaged under the International Plan of Action (IPOA).

Unregulated fishing, the third perspective, has two distinct aspects. The first one refers to activities carried out within the regulatory competence areas of RFMOs, but by vessels that are either not flagged to any State or are flagged to a State that has not agreed to abide by the RFMO rules. The second one refers to activities that undermine or contravene international law where there is no applicable regional regulation. Although the term unregulated fishing has been predominantly associated with high-seas fishing activities ${ }^{3}$, subparagraph 3.3.2 potentially concerns EEZ stock in circumstances where the coastal State has not exercised prescriptive

3 See Agenda 21, paragraph 17.45, and the Preface of the FAO Code of Conduct for Responsible Fisheries, Rome, 1995. The FSA also makes reference to unregulated fishing in its Preamble. 
jurisdiction appropriately and has left regulatory voids that leave stocks unprotected. Paragraph 3.4 of the IPOA seems to suggest that paragraph 3.3 is intended to capture activities that evidence underlying inconsistencies with international law (Theilen 2013). The implication of this, with regard to subparagraph 3.3.1, is that the activities referred to therein must be inconsistent with the regulatory State's obligations under international law, even if this is not specifically stated in the paragraph. Hence, the intention of paragraph 3.4 is to bring paragraph 3.3 in its entirety in line with the two previous paragraphs, and all of the activities to which they refer, as the bases for the adoption of the market and other measures set out in subsequent parts of the IPOA.

The description of IUU fishing contained in the IPOA is of relevance to the coastal State in respect of each of the three perspectives, insofar as all three potentially refer to fishery activities that may contravene or undermine legal conservation and management rules in the EEZ, or that are otherwise exploitative of deficits in domestic fishery regulation.

\section{Drivers and Global Impacts of IUU Fishing}

The drivers of IUU fishing are predominantly financial: gains are derived from the ability to trade with undiscerning markets and enhanced by evading regulatory costs. (Flothmann et al. 2010) Given the regulated nature of fisheries activities, the perpetuation of IUU fishing is facilitated by deficiencies in regulatory frameworks and by a lack of rigorous execution by the public authorities with responsibility for fishery governance. ${ }^{4}$

An important part of the impacts derived from overfishing are believed to be attributable to IUU Fishing (FAO 2014). Broadly, these encompass fish-stock depletion (Agnew et al. 2009) as well as the erosion of food and work security in diverse fishery-dependent human

4 For further information on the effects of deficient governance, see Le Gallic, Bertrand, and Anthony Cox, "An Economic Analysis of Illegal, Unreported and Unregulated (IUU) Fishing: Key Drivers and Possible Solutions." Marine Policy 30, no. 6 (2006): 689-95. Also, see Pauly, Daniel. "Beyond Duplicity and Ignorance in Global Fisheries." Scientia Marina 73, no. 2 (2009): 215-24. 
Despite the difficulties associated with the detection and recording of infractions, IUU fishing is widely thought to inflict vast costs to the global economy, with a frequently cited study suggesting between US $\$ 10$ and 23.5 Billion per annum (Agnew et al. 2009). According to a 2015 publication by the European Union (EU), costs might be in the region of Euro 10 Billion per year, which corresponds to $19 \%$ of the worldwide reported value of catches (EU Directorate of Maritime Affairs). Least-developed countries are among the most vulnerable, due to the fact that reliance on fish for nutrition tends to be greater than in developed countries, (FAO 2014: p 7; Allison, E. H. et al. 2009) and reliance on production and exportation of fish products is also greater (54\% of all fish exports by value, and over $60 \%$ by quantity) (FAO 2014: p 8), while ability to plan and execute adaptation to biomass reduction is diminished by a lack of capacity (Allison et al. 2009).

IUU fishing undermines the long-term profitability of the fishing industry, being not only a resource drain but also a source of unfair competition to lawabiding fishers: as IUU fishing operators are unencumbered by regulatory and legal constraints, they benefit from quota diverted from legal fishers and income withheld from fisheries authorities (Stokke 2009). In turn, the presence of IUU fishing can intensify pressure on authorities to increase quotas, as well as undermine fishers' appetite for compliance (ibid.).

Further, as those who engage in IUU operations must act covertly, they contribute to the emergence and perpetuation of corruption in seafood production and distribution chains (Standing 2008; Sundstrom 2012). The secrecy and unpredictability that characterise many IUU fishing operations can pose serious difficulty to fishery managers entrusted with the detection of illicit activity and the identification of the vessels involved (Rashid \& Pramod 2010). IUU operations undermine the rule of law and may

5 See also: Srinivasan, U. Thara, William W. L. Cheung, Reg Watson, and U. Rashid Sumaila. "Food Security Implications of Global Marine Catch Losses due to Overfishing." Journal of Bioeconomics 12, no. 3 (2010): 183-200. Garcia, Serge M., and Andrew A. Rosenberg. "Food security and marine capture fisheries: characteristics, trends, drivers and future perspectives." Philosophical Transactions of the Royal Society of London B: Biological Sciences 365.1554 (2010): 2869-2880. Le Manach, Frederic, Charlotte Gough, Alasdair Harris, Frances Humber, Sarah Harper, and Dirk Zeller. "Unreported Fishing, Hungry People and Political Turmoil: The Recipe for a Food Security Crisis in Madagascar?" Marine Policy 36, no. 1 (2012): 218-25. Flückiger, Matthias, and Markus Ludwig. "Economic shocks in the fisheries sector and maritime piracy." Journal of Development Economics 114 (2015): 107-125. 
facilitate transnational crimes, (UNGA Res. 63/1 12 2008) 6 with investigative work undertaken in recent years serving to highlight the vulnerability of the sector to trafficking of persons, slavery and the transportation of drugs (EJF 2011).

\section{IUU Fishing in the Exclusive Economic Zone}

Collectively, EEZs cover only $35 \%$ of the total ocean area but contain around $90 \%$ of the world's fish stocks (Fact sheet EU 2015), including species that are attractive to operators, due to their economic value. IUU fishing activities taking place in the EEZ have direct detrimental impacts on the domestic economies that ought to benefit from the economic potential of such stock. First, insofar as IUU fishing may impact artisanal fisheries, given their generally higher contribution to employment, it undermines work security. For example, coastal African communities are comparatively vulnerable, as artisanal fisheries contribute $0.43 \%$ to the GDP, versus the 0.36 contributed by industrial marine fisheries, while employing the vast majority of national vessels. It has been estimated that addressing IUU fishing in the West African region and developing fisheries appropriately may create more than 300,000 jobs (ODI 2016). Second, the illegal capture of certain domestic high-value species, coupled with discards and extensive underreporting, is thought to have significant detrimental effects on the sustainability of affected economies (FAO 2014: p 13). Commercially important species, such as cephalopods, shrimp, demersals and small pelagics, are believed to be overexploited, with around $48 \%$ of West African stock believed to be captured to unsustainable levels (ibid: p 39).

Certain patterns characterise IUU fishing operations. A lack of transparency and unclear administrative structures in some States facilitates misreporting as well as irregular access by foreign vessels to domestic stock. ${ }^{7}$ Yet,

6 See also: UN Office on Drugs and Crime, Transnational Organized Crime in the Fishing Industry: Focusing on Trafficking in Persons, Smuggling of Migrants and Illicit Drugs Trafficking, Vienna, 2011.

7 On the subject of the link between IUU fishing and private licensing, see EJF press release, Bold Action Taken by Korea to Combat Illegal, Unreported and Unregulated (IUU) Fishing Shows EU IUU Regulation is Working (2015). The importance assigned to private licensing verification protocols by the Spanish government in the fight against IUU fishing is reflected in its 2015 agreement with Curaçao. Official announcement available at http://www.lamoncloa. gob.es/lang/en/gobierno/news/Paginas/2015/20150724-illegalfishing.aspx 
despite commonalities in modi operandi, IUU fishing is not exclusive to particular ocean regions.

By way of illustration, in West Africa, according to FAO records, save for Guinea Bissau and Mauritania, coastal States provide insufficient information on volumes and composition of foreign vessel captures in their EEZs, eroding the accuracy of catch estimates. Cross checking of submissions is hampered by joint venture operations and chartering arrangements between distant water vessels and local companies, which makes catch attribution and traceability more challenging (ibid: $p$ 12). Inevitably, fragile States with resource-rich waters, endemic poverty and high perceived levels of systemic corruption are particularly vulnerable to the irregular fishery access practices frequently linked to IUU fishing (Agnew et al. 2009; Standing 2008).

It is important to note that deficiencies in connection with data reporting are not unique to fisheries dependent on developing countries for their regulation. ${ }^{8}$ The effect of suboptimal monitoring, recording and datasharing practices is serious, with recent research suggesting there is an astonishing asymmetry between official figures and the likely reality of captures, with systematic underreporting believed to have been as high as $53 \%$ in recent years (Pauly \& Zeller 2016).

The link between deficient coastal State control and the proliferation of IUU fishing in the EEZ is also illustrated by events of recent years in Thailand. The European Commission issued a warning to Thailand in 2012 in respect of the presence of IUU fishing products in exports to the EU (Commission decision 2012). According to this communication by the European Commission, over $95 \%$ of catches, including those of the artisanal fleet, may have been underreported to Thai authorities as a result of endemic deficiencies in domestic fishing vessel registration practices. These were compounded by systemic data-sharing failures resulting from tensions and administrative discrepancies between the different departments involved in fisheries regulation. As a result, overexploitation and uncontrolled competing pressure on decreasing resources led to more of the local vessels resorting to illegal and destructive practices to secure captures (ibid.). Further, civil society reports have linked the absence of

8 See, for example, the General Fisheries Commission for the Mediterranean (GFCM), Report 39, Milan, 2015, paragraph 57. 
adequate fishery controls in Thailand to the emergence of wrongs of a criminal nature, with the reliance on migrant smuggling to secure cheap work on board fishing vessels flagged as a particularly prevalent problem. According to these accounts, foreign persons that were often unskilled and unable to communicate effectively had been indentured to work on Thailand's fishing vessels and regularly subjected to inhumane working conditions, torture and even murder at the hands of captains and the senior crew. 9

Hence, in addition to being detrimental to stocks and their environment, to the rule of law and to the effectiveness of fisheries governance, IUU fishing inflicts detrimental impacts on diverse human populations and undermines the fabric of fisheries economies. These effects justify the inclusion of IUU fishing in maritime security strategies. ${ }^{10}$ IUU fishing can be understood as a threat to human security (Bueger 2015), irrespective of whether it occurs domestically or beyond areas of national jurisdiction.

\section{The Importance of Coastal State Governance}

Much attention has been paid in international legal literature to the governance of high seas (Molenaar 2007; Serdy 2011; Barnes 2012; Elferink 2012; Takei 2013) and to deficient control of fishing vessels by flag States (Bratspies 2001; Warner Kramer 2004; Rayfuse 2005; Erceg 2006; Miller 2014). This is not surprising, given the high commercial value of straddling and highly migratory species, such as tuna and billfishes. One of the most important treaties for the governance of wild fisheries, the 1995 Fish Stocks Agreement (FSA) (Agreement 1995), is exclusively concerned with their regulation. Although the FSA may shape the conservation and protection of straddling and highly migratory stock partly occurring in the EEZ (ibid: Art. 5), neither it nor another important treaty for the purposes of IUU fishing

9 See EJF audio-visual reports Sold to the Sea and Pirates and Slaves: http://ejfoundation.org/video/sold-sea-humantrafficking-thailands-fishing-industry-0 and http://ejfoundation.org/report/pirates-and-slaves-how-overfishing-thailandfuels-human-trafficking-and-plundering-our-oceans For other examples of crew abuses on board of fishing vessels, see Ian Urbina's Stowaways and Crimes Aboard a Scofflaw Ship, New York Times, available at http://www.nytimes. com/2015/07/19/world/stowaway-crime-scofflaw-ship.html

10 The EU has formally included IUU fishing in their Maritime Security Strategy. Further information can be obtained here: http://eeas.europa.eu/maritime_security/docs/maritime-security-information-toolkit_en.pdf. 
control, the 1993 Compliance Agreement (Agreement 1993), extend to the regulation by coastal States of stock that occurs exclusively within an EEZ.

Yet, governance by the coastal State of EEZ resources is at least of equal importance. EEZs not only harbour the vast majority of the ocean's living resources (Barnes 2006: 233), but, as already stated, they also form part of coastal economies and make an important contribution to the international economy through exports, fishery support activities and the granting of access to foreign fleets.

\section{Coastal State Governance of EEZ Resources and International Law}

The protection of the resources of the EEZ and their interlinked environments is entrusted to coastal States under international law, which is a reflection of the sovereign rights they hold for the exploration and exploitation of the EEZ's economic potential (LOSC: Art. 56.1. (a) and (b)). Where stocks are transboundary, meaning they occur in part outside of the EEZ, due to migratory patterns or habitat geography, their good management requires cooperation, either with other States or through participation in RFMOs or similar bodies (LOSC: Art. 118). Such participation involves regular discussion in regard to institutional rules, collective rationalisations and expectations and supervisory and data-checking processes that can be absent in respect of the regulation of stock not requiring cooperation with an RFMO."1

In order to manage fisheries and control IUU fishing, coastal States employ domestic public law and regulation, and these tools may be conditioned by a number of international legal prescriptions and limitations. First, insofar as fishing activities and processes in the EEZ may impact components of

11 See, for example, the second paragraph after question 4, on page 16 of the written statement submitted to the International Tribunal for the Law of the Sea by the Sub-Regional Fisheries Commission in their Request for an Advisory Opinion, available at: https://www.itlos.org/fileadmin/itlos/documents/cases/case_no.21/written_statements_ round1/C21_19_CSRP_orig_Eng_rev.pdf. 
marine biodiversity, domestic fishery management is of interest to the legal regime established by the 1992 Convention on Biological Diversity (Barnes 2010: 543). Second, the presence of species vulnerable to extinction in the fishery may make the trade of specimens of concern under the 1973 Convention on International Trade in Endangered Species of Wild Fauna and Flora (CITES) (Convention 1973). Most importantly, for the purposes of IUU fishing control, the conservation of marine-living resources is a stated objective of the LOSC, which specifies in its Preamble: 'Recognizing the desirability of establishing through this Convention, with due regard for the sovereignty of all States, a legal order for the seas and oceans which will facilitate international communication, and will promote the peaceful uses of the seas and oceans, the equitable and efficient utilization of their resources, the conservation of their living resources and the study, protection and preservation of the marine environment' (LOSC Preamble: $p 4$ ).

Despite the fact that the implementation of the conservation provisions contained in parts V and XII of the LOSC is important for the development of IUU fishing control measures in the EEZ, compliance can, in many cases, be considered deficient (Churchill 2012: 813). Observance of the conservation obligations of the LOSC is an inherent part of the exercise of the sovereign rights assigned by the Convention to coastal States in respect of the utilisation of their EEZ (LOSC: Art. 56, 61, 193). However, Part $V$ of the LOSC affords coastal States a wide margin of discretion in determining where the balance between conservation and utilisation should rest. The implication of the Part $\vee$ provisions is that coastal States must make sure that the living resources of the EEZ are not subjected to overexploitation and are maintained at sustainable levels (LOSC: Art. 56.1 (b) (iii) and 61). For example, coastal States must determine the total allowable catch in the EEZ (LOSC: Art. 61.1.), and this must be done by taking into account the best scientific evidence available to the coastal State and subject to an obligation to ensure that the resources are not overexploited (LOSC: Art. 61.2.).

Adopted measures must ensure that stocks can produce their maximum sustainable yield, but conservation is conditioned by certain qualifications (Barnes 2006). These include environmental and economic factors, such as the needs of coastal communities and developing States, among other possible elements (LOSC: Art. 61.3). Subject to this, the coastal State 
must have in place a suitable domestic regime that ensures the optimum utilisation of the marine-living resources in their EEZs (LOSC: Art. 56.1 (b) (iii), and Art. 62.1.). In order to achieve this, the coastal State shall determine its own harvesting capacity, and where it cannot harvest the entire allowable catch, it shall make arrangements with other States to permit their fleets access to any surplus (LOSC: Art. 62.2) for which the LOSC allows a wide degree of discretion (LOSC: Art. 62.3.). In specifying the conditions upon which the nationals of other States may operate in its EEZ, the coastal State is enabled to put in place measures such as licences, fees and other forms of financing and compensation, specification of catches and capture periods, seasons, fish age and size, specification of gear, sampling, placing of observers, data sharing, cooperative arrangements' terms and conditions and enforcement procedures (LOSC: Art. 62.4(a) to (k)). These conservation and utilisation provisions may have achieved international customary law status, which would imply that they are obligatory, even for States that have not ratified or acceded to the LOSC (Markovski 2009: 13), but their generality means that they are open to interpretation (Barnes 2006: p 237), and such open texture means that they are less than ideal for operationalisation as effective conduct standards.

Insofar as IUU fishing control is concerned, the LOSC is ostensibly silent. However, its conservation provisions have been given some additional specificity in that regard by the ITLOS in the Request for an Advisory Opinion Submitted by the Sub-Regional Fisheries Commission (ITLOS 21) (ITLOS Reports 2014: p 404). ITLOS 21 emphasises the conservation obligations of the coastal State as specifically incorporating the protection of the resource against vessels engaged in IUU fishing (ITLOS 21: p 16). This is implied also in respect of the obligations to determine allowable catches in the EEZ and 'to ensure' that the resources are not overexploited, through the adoption of adequate laws, regulations and enforcement measures (ITLOS 21: p 104, 105). Hence, the obligation to address IUU fishing is assigned to the coastal State (ibid: $p$ 106) as part of its general obligations to conserve and develop the living resources in the EEZ. These are set out in LOSC Article 63.1, which, according to the ITLOS, underpins the meaning of 'sustainable management' (ibid: $p$ 189, 191). ${ }^{12}$

12 The general obligations and rights of the coastal State in respect of the conservation and management of fisheries are contained in LOSC Articles 61, 62, 73, 192 and 193. 
Further clarity in respect of the nature of these obligations is afforded by ITLOS by way of reference to the Advisory Opinion for Responsibilities and Obligations of States with Respect to Activities in the Area ${ }^{13}$, where the Seabed Disputes Chamber held the view that a 'responsibility to ensure' implies the need for obligations derived from international law to become effective for private actors operating under domestic law; this involves the fulfilment of international obligations by States through their conduct, namely by exercising their power over the domestic actors under their control (ITLOS 21: p 108). The nature of these obligations is not that of achieving a specific result but 'to deploy adequate means, to exercise best possible efforts, to do the utmost, to obtain this result' (ITLOS 21: $\mathrm{p}$ 110). In essence, this is a 'due diligence' obligation (ITLOS 21: p 111), which implies the adoption and enforcement of regulatory measures and vigilance in the exercise of administrative controls, such as the monitoring of activities by private operators. ${ }^{14}$

The elaboration by ITLOS of the detail of these provisions ostensibly refers to the duties of the flag State. However, the Tribunal clarifies in paragraph 124 that the responsibilities for the conservation and management of the resources of the EEZ under the LOSC, including the adoption of legal and regulatory compliance measures, correspond to both the flag and the coastal State, with the latter in fact bearing the primary responsibility (ITLOS 21: p 115, 124). This equation in the nature of responsibilities is logical, particularly since the coastal State is also the flag State for the purposes of the control of domestic vessels operating in the EEZ. Hence, coastal States are expected to deploy a wide range of prescriptive measures of a legal, regulatory and administrative character, as well as enforcement measures enabling inspection and boarding, arrest and the commencement of judicial proceedings (ibid: $\mathrm{p} \mathrm{105)}$ ) and to impose penalties in accordance with the provisions of the LOSC (LOSC: art. 73).

There are no binding international legal parameters of which fishery conducts must be addressed in respect of non-transboundary EEZ stock. A list of activities is found in FSA Article 21.11, which, before the term IUU fishing had officially been coined, had typified specific activities that it

13 Responsibilities and obligations of States with respect to activities in the Area, Advisory Opinion, 1 February 2011, ITLOS Reports 2011 , p. 10, at p. 41, as cited at ITLOS 21, paragraph 128.

14 As per the Case Concerning Pulp Mills On The River Uruguay, (Argentina V. Uruguay), Request For The Indication of Provisional Measures. ICJ Reports, 2007, p. 77, paragraph 187, also cited at ITLOS 21, paragraphs 128 and 131. 
referred to as 'serious violations' (FSA : Art. 21.11.). Among these, some specifications, such as falsifying or concealing the markings, identity or registration of a fishing vessel (ibid: Art. 21.11 (f)) or concealing, tampering with or disposing of evidence relating to an investigation, (ibid: Art. $21.11(\mathrm{~g})$ ) aim at the heart of IUU fishing practices. Although the obligations contained in FSA Article 21, in respect of serious violations, are primarily directed at members of RFMOs undertaking at-sea inspections and atvessel flag States; coastal States parties to the FSA must address them where relevant in the context of their cooperation with RFMOs. ${ }^{15}$ However, these provisions only apply to straddling and highly migratory stock, not extending to the management of species outside RFMO management.

A more-extensive list, including transhipment, is included in European Council Regulation (EC) 1005/2008 (Council Regulation 1005/2008), referring to vessel activities not limited to highly migratory and straddling stock or areas under the management of RFMOs (EU Council Reg. 2008). Yet, this list is only relevant to States that are members or trading partners of the European Union. Finally, despite these requirements to address specific vessel activities, important coastal State obligations remain too general. For instance, the specifics of what constitute the adequate assessment of biomass or the optimum determination of TAC and quota distributions are ultimately left at the discretion of the coastal State and whatever economic interests it chooses to serve.

By contrast, a number of conduct standards for fighting IUU fishing are specified in considerable detail in the IPOA IUU, which is not legally binding. These voluntary norms include, inter alia, the elaboration of evidentiary and admissibility standards, including the use of electronic evidence (IPOA IUU: $p$ 17), the deployment of adequate monitoring, control and surveillance mechanisms (ibid. p 24), the elaboration of a penalty regime outside the rigours of criminal proceedings (ibid. p 21), the carving of an evidentiary role in judicial proceedings (ibid. p 51) and the introduction of enhanced reporting requirements, (see: Edeson 2000) ${ }^{16}$ to name but a few.

15 FSA, Article 7, specifying compatibility measures applicable to coastal States.

16 According to Edeson's report, such requirements had previously been introduced in other international and domestic instruments, such as the Treaty on Fisheries Between the Governments of Certain Pacific Island States and the Government of the United States of America and the US Lacey Act. 


\section{B Brief Introduction to Accountability}

Accountability in a general sense refers to the vast array of public and non-public mechanisms whereby a community in pursuit of desired policy objectives balances order and freedom (Dubnick \& Yang 2009). The myriad potential adaptations of which accountability is capable within this very broad definition enable it to transcend traditional disciplinary boundaries (Rached 2016). In the global governance arena, accountability mechanisms may include a wide range of legal and non-legal norms, requirements, conditions and standards and their associated processes and protocols, articulated for the purpose of learning, assessing and shaping the conduct or performance of an international actor (Grant \& Keohane 2005; Bovens 2007). The conduct rules that are relevant to IUU fishing control are established in general norms of international law, normative treaty provisions, non-binding rules derived from voluntary international instruments, as well as domestic law and regulation, and regional legal and non-legal rules. Hence, promoting adequate responses by coastal States in the EEZ to such an array of rules requires a plurality of accountability mechanisms. Availability of mechanisms should not be reduced to what is available in the domestic realm, if human security and the promotion of opportunities for meeting important human needs, such as nutrition and work, are to be addressed fairly. While options in respect of the accountability of the State's administrative agencies will likely be richer and more coherently articulated in the domestic sphere, the effects of deficient regulatory performance by the coastal State can be felt beyond its national boundaries (see Mashaw 2006). Exclusively domestic mechanisms may be inaccessible to some of those upon which such effects fall.

In the context of relationships between and amongst international actors, where certain expectations of performance exist in respect of shared or common interests, accountability has often been equated with data-sharing processes that seek to improve management and foster transparency (Krisch \& Benedict 2006). While there can be little doubt that transparency is essential for accountability, some authors also argue that one of the key implications of accountability is that potential ex-post-facto consequences should follow transgressions or shortfalls in performance against assumed obligations and related conduct standards (Grant \& 
Keohane 2005). Whether the need for consequences is accepted as a necessary aspect of accountability or not, ascertaining the existence and nature of the rules under which conduct expectations are formed is an essential first step in ascertaining whether and how accountability may be facilitated.

\section{Accountability Mechanisms Incorporating Legal Rules of Conduct}

In order to understand whether traditional international law can facilitate accountability in respect of coastal State deficiencies in IUU fishing control, it is first necessary to explore whether specific norms may function as an appropriate rule of conduct against which assessments can be made. Traditional international law contains a chapter in the form of the rules of State Responsibility, as codified by the International Law Commission (ILC) by way of the Articles on the Responsibility of States for Internationally Wrongful Acts (ARSIWA) (ILC Draft Articles 2001: p 26). While it may seem axiomatic that, in the exercise of their rights, States must comply with their international legal obligations (Crawford 2012: 450), acts and omissions by States may, under certain circumstances, give rise to an international wrong in respect of which the State will be deemed responsible (Shaw 2008: 781). According to Article 2 of ARSIWA, an international wrong occurs when an international legal obligation that was attributable to a State has been contravened (ILC Draft Articles 2001). In respect of this attribution requirement, it must be pointed out that, under normal circumstances, IUU fishing is carried out by private operators and not by or on behalf of States. But as already discussed, the notion that the State has obligations to prevent damaging activities by persons under its control has been well established through the principle of due diligence (Tzevelekos 2010). Under the LOSC, coastal States have conservation obligations, and this extends to obligations to regulate and control fishing activities in the EEZ. This involves the need for coastal States to exercise their power over operators carrying out IUU activities under the State's own domestic law. While the conduct of such persons may not be carried out on behalf of the coastal State, the State may fail in applying sufficient 
diligence and vigilance in the exercise of its obligations and thus become internationally responsible. Such Responsibility implies the breach of a binding international obligation. The conservation obligations of the LOSC are indeed binding in nature, but their generality, conditionality and absence of relevant transparency provisions undermines their potential as conduct rules with which to facilitate the accountability of the coastal State (Barnes 2006: p 239).

Much-more-defined State conduct rules in respect of all State and specific coastal State IUU fishing control have been established in the IPOA IUU. The IPOA was constructed under the auspices of the UN and for which there is wide endorsement by States (Palma et al. 2010: 95). Despite this, its non-binding nature has the effect of emasculating the efficacy of the conduct standards it contains in the strict context of State Responsibility, except where specific provisions have been integrated into domestic law.

Particularly limiting is the provision in Part XV of the LOSC, whereby coastal States are exempted from having to accept submissions from other States in the context of judicial disputes involving sovereign rights with regard to EEZ fisheries, including harvesting management and conservation (LOSC : Art. 297.3 (a)). As coastal States are excluded from the scope of the compulsory procedures of the Convention, entailing binding decisions, the LOSC specifies that any such disputes be instead resolved by conciliation for amicable settlement (LOSC : Art. 297.3(b) (i)), including in cases where it may be alleged that the living resources of the EEZ are seriously endangered. The LOSC is specific in underlining that the discretion of the coastal State is paramount for the purposes of conciliation (LOSC: Art. 297.3(c)). It is therefore doubtful that conservation decisions made by the coastal State, including those related to IUU fishing control, may be challengeable through the judicial mechanisms of the LOSC.

Perceived contraventions of legal obligations may also result in unilateral processes involving restrictive measures of an economic nature in order to influence the behaviour of the State perceived to be in breach, carried out within the framework of the World Trade Organisation (Chamovitz 2001). ${ }^{17}$ For instance, a fishery may be harvested only domestically, but in an

17 Churchill (2012) argues that unilateral measures of this kind, such as the measures taken by Chile against the European Union in the months that preceded the Swordfish litigation, can be understood as a type of countermeasure. 
increasingly inter-dependent world, a proportion of the resulting seafood products may be destined to international markets. Communities in other States may rely on such products, whether as a source of work or nutrition. Those States may perceive the IUU activities in the coastal State as being detrimental to their nation and/or their policies, and they may seek ways to induce compliance with fisheries conservation norms by way of trade measures. The European Union has established one of the most important mechanisms of this nature by virtue of Council Regulation 1005/2008 (the IUU Regulation). This regime is primarily targeted at the accountability of flag States ${ }^{18}$, but is also relevant to cases where domestic stock harvested by the coastal State's own national vessels is subsequently exported to the EU, as, in these circumstances, the coastal State will also be the flag State. The interactive mechanism in the IUU Regulation works by way of a system of port notice and access authorisations (Council Regulation 1005/2008: Art. 6 to 8) and inspection procedures (ibid: Art. 9 to 11 ) combined with the utilisation of catch certificates for importation and exportation of fishery products (ibid: Art. 12 to 16). The catch certificates must be validated by the third country vessel's flag State (ibid: Art. 15.1) and may be subject to verification processes carried out by the competent authorities of a member State of the European Union (ibid: Art. 17.2). Irregularities with the catch certificate or the products it accompanies may result in a number of negative consequences. These may include the refusal of importation of a consignment (ibid: Art. 18), if it is not accompanied by a catch certificate or is accompanied by one that misrepresents the products, is not validated by the right authority, is incomplete, does not meet indirect importation rules, has been caught by a vessel in an IUU vessel blacklist or has been validated by a flag State identified as non-cooperating (ibid: Art. 18.1 (a) to (g)). Sanctions linked to IUU fishing may include black listing of vessels (ibid: Art. 27 and 30) and, following a dialectical process of information, the issuance of a public warning of pending non-cooperating status, which may culminate in the suspension of market access until the identified cooperation deficits have been addressed (ibid: Art. 33 and 35).

The market mechanism established by the IUU Regulation allows sufficient flexibility to permit conduct assessment against legal norms as well as quasi-legal standards of conduct, such as the rules of the RFMOs for States that have either adopted membership or agreed to cooperate with

18 For an overview of the rationale of the trade measures deployed by the EU, see the Preamble to Council Regulation 1005/2008, paragraphs 5, 9, 13 and 31 . 
these organisations (ibid: Art. 31.3 and 31.6 (b)). Further, in the context of this mechanism, legal norms have been interpreted by reference to the more-specific rules of the IPOA. ${ }^{19}$

Despite these strengths, however, regimes of this nature have limitations. First, in contrast to access agreements, these mechanisms have little reach in cases where the domestic stock has been harvested in the EEZ by foreign vessels, as the trade-related measures upon which it relies as ultimate sanctions are imposed on the exporting nation, which is not the coastal State but the fishing vessel's flag State (ibid: $p$ 10). ${ }^{20}$ Second, while one of its advantages is that it can rely on standards contained in the quasi-legal rules of the RFMOs, these are not directly relevant to the protection of non-transboundary domestic stock: where they address IUU fishing activities, these rules involve capture activities vis-à-vis the stock they manage in their regulatory areas, which will normally occur at least partially in the high seas. Last, market accountability, even if underpinned by a substantial legal and regulatory framework, is no substitute for judicial processes, as it is not only able to directly contribute to legal interpretation but is also less sensitive to the relative power of the parties to the dispute (Charnovitz 2001). By contrast, market-related mechanisms are unlikely to be either resisted or deployed by the less economically developed States or by those with dependent markets (Grant \& Keohane 2005). Inevitably, inter-State (or inter-public, if one party is a supranational entity like the EU) accountability mechanisms with a marked economic component favour hegemonic markets, which are able to interpret and develop accountability conduct rules and standards to their preferences.

Other opportunities for accountability may be created where harvesting States wishing to reinforce conservation and the rule of law may, for instance, increase their use of bilateral or multilateral fisheries agreements. Such agreements usually emphasise conduct rules for vessel operators and flag States but may also establish specific regimes for cooperation between the flag and coastal States that may otherwise be missing. This is particularly so

19 By way of illustration, Commission Decision of 21 April 2015 in respect of the Kingdom of Thailand, which states at sub-section 3.3 paragraph (80), in reference to Thailand's domestic legislation development with respect to fishery management, interpreting a framework legal rule by incorporation of a non-legal rule: Finally, a deterrent sanctioning scheme is not included which undermines Thailand's capacity to fulfill the requirements of Article 73 of UNCLOS regarding enforcement of laws and regulations, and point 21 of the IPOA IUU.

20 However, foreign vessels operating under bareboat charter or joint venture arrangements may export under the nationality of the coastal State. 
in alternative scenarios, where vessels operate under private licenses with a coastal State. ${ }^{21}$ Access agreements have the potential to add considerable definition and depth to the conservation and management obligations of the LOSC. They may, among other possibilities, incorporate provisions on scientific cooperation, transparency and sensitive operational issues, such as vessel tracking and transhipment. Further, where domestic stocks are shared between the flag and coastal States through medium to long-term agreements, the mutual expectations they create in respect of on-going interests and their associated obligations may foster efforts in attaining and maintaining sustainability. Shared efforts can be reinforced if both States keep making each other accountable through mutually acceptable disclosure, supervision and dialogue procedures and a mutually agreedupon system of rewards. Additionally, where such agreements are able to supersede the frequently opaque private licensing agreements mentioned above, they have the potential to make a significant contribution to transparency that, in turn, can only strengthen the accountability of all parties and actors relevant to the agreement. The ability of fisheries agreements to contribute towards better fishery regulation has been duly noted by the ITLOS (ITLOS 21: 32, p 114, 115).

Indirect international accountability strategies beyond the limited options afforded by these approaches does exist, albeit not concerned directly with fish stock management or vessel control. Tangential mechanisms may include the reporting and compliance procedures under CITES in respect of the trade in endangered marine wildlife captured in the context of an IUU fishing operation (CITES 1973: Art.8 p. 7). These mechanisms, though not devoid of potential, are currently of limited relevance to the conservation of commercial stock vulnerable to IUU fishing.

\section{Other Miscellaneous Accountability Mechanisms}

The collective trade-related measures deployed by RFMOs and other multilateral environmental agreements are rarely directly relevant for the

21 For concerns raised in respect of such practices, see ITLOS 21, pp. 49, paragraph 176. 
protection of domestic non-transboundary stock. Market- and port-entry denial, vessel black lists and product documentation have and continue to be deployed as measures to combat IUU fishing. The same criticism levelled at the IUU Regulation can be applied to these mechanisms in respect of market asymmetries (Stokke 2009). In particular, RFMOs can only address IUU fishing activities involving the stock they manage in their regulatory areas, which by definition will be straddling, highly migratory or discrete to the high seas, and will exclude non-transboundary domestic stock.

While accountability in the mechanisms specified in the above paragraphs are inter-public and can be demanded by States or international organisations, other mechanisms exist with some potential to foster accountability in respect of IUU fishing control, albeit without directly engaging the coastal State in a unitary sense. Certification standards, such as those promoted by the Marine Stewardship Council, can contain inbuilt mechanisms able to identify and filter IUU captures; these may include monitoring, transparency and traceability requirements that are mandatory throughout the supply chain and rules that prevent scheme participants from trading IUU products (Agnew 2015). Through fisherydeveloping guidelines, less-developed coastal States may be able to benefit from Western economy commitments to sustainable sourcing, and through the interface of certification programmes and associated training mechanisms, practices and governance may be improved following a bottom-up approach. In this kind of market accountability, the State is not engaged directly; it is the fishery enterprise that commits to meet sustainability, environmental impact and effective management standards of a technical nature, which are independently assessed (MSC 2014a). There is no direct engagement vis-à-vis other States either, but transnationally to an entity that acts as mediator with the retail industry and, ultimately, consumers. The mechanism is able to foster accountability, insofar as it contains supervisory and transparency mechanisms over producers as well as incentives that may be lost if conducts deviate from established standards, including tracking and benchmarking indicators for projects with sustainability potential but need of improvement (MSC 2014b). Further, its associated governance and sustainability benefits should benefit dependent communities as well as support stock recovery and fishery development, while disincentivising 
IUU fishing (Anderson 2016). Approaches such as these are promising and contain much potential but will need substantial effort by those concerned as well as other actors, such as civil society, before visible improvements in coastal State governance become evident. Civil society may need to explore potentially complementary domestic mechanisms able to counterbalance the effects of poor governance in respect of IUU fishing control. These may involve rights of an administrative nature, such as participation and due process, if domestic legislation provides avenues for such bottom-up approaches to accountability. This may, for example, involve the provision of management rights or the ability to demand a review following the exclusion of affected communities from certain interventions and decisions that significantly undermine the relied-upon resources (Dellinger 2013), such as decisions involving foreign access to fisheries. However, this approach only serves communities able to trigger domestic tools of an administrative or legal nature, leaving impacts beyond the boundaries of the coastal State unaddressed. Notably, Goal 16 of the UN Sustainable Development Goals, namely, to 'promote peaceful and inclusive societies for sustainable development, provide access to justice for all and build effective, accountable and inclusive institutions at all levels', is directly relevant (UNGA Res. 70/1 2015) and calls for reflection upon how these mechanisms could be made more inclusive and comprehensive. The relationship between the sound management of domestic fisheries and the development of domestic administrative approaches to State agency accountability, particularly in vulnerable and developing countries, is also synergistic with the objectives of the Rio 20 Declaration, The Future We Want, in the context of development and the rule of law (UNGA Res. 66/288 2012). 


\section{ค Conclusion}

Given the integral globalisation of the marine fisheries' capture and trade sector, and the fact that deficient IUU fishing control in the EEZ can have detrimental effects on communities inside as well as outside the coastal State, there is a need to develop mechanisms able to foster the accountability of the coastal State at the international, transnational and domestic levels. Although not completely absent and harbouring some complementarity and potential for further development, current mechanisms are insufficient. International adjudication under the LOSC is largely inoperative in respect of coastal State sovereign rights and corresponding obligations in the EEZ. The supervisory and transparency mechanisms established by RFMOs tend to exclude non-transboundary EEZ stock, and existing international market mechanisms are not capable of providing accountability in respect of some important aspects of coastal State governance, such as the activities of foreign vessels in the EEZ as well as being less effective against larger fishing nations. While this could be counteracted with further reliance upon access agreements, there is evidence that States in areas where IUU fishing is chronic continue to deal with operators directly, to the inaction of the relevant flag States in almost complete opacity. Indirect mechanisms are tangential, and domestic remedies are also limited and acknowledged as needing support in the areas where IUU fishing is most common, namely lessdeveloped and fragile States. In line with the high profile that IUU fishing has acquired in recent years in international agendas, global governance frameworks for IUU fishing control are developing rapidly. However, coastal State accountability, whether direct or indirect, lags behind in the growing regulatory landscape. More efforts are needed on the part of governments, industry and civil society to ensure possible mechanisms are fully explored and, where possible, developed. 


\section{Bibliography}

Agnew, D., 2015. Marine Stewardship Council (MSC), Tackling Illegal Fishing One Certificate at a Time. Available at: http://blog.msc.org/ blog/2015/04/01/tackling-illegal-fishing-one-certificate-at-a-time/.

Agnew, D. J., Pearce, J., Pramod, G., Peatman, T., Watson, R., Beddington, J. R. and. Pitcher, T.J., 2009. Estimating the Worldwide Extent of Illegal Fishing. PLOS ONE 4, no. 2.

Agreement for the Implementation of the Provisions of the United Nations Convention on the Law of the Sea of 10 December 1982 relating to the Conservation and Management of Straddling Fish Stocks and Highly Migratory Fish Stocks. 1995. 2167 UNTS 3.

Agreement to Promote Compliance with International Conservation and Management Measures by Fishing Vessels on the High Seas. 1993. 2221 UNTS 91.

Allison, E. H., Perry, Perry L.P., Badjeck, M.C., Adger, W. N., Brown, K., Conway, D., Halls, A.S. et al., 2009. Vulnerability of national economies to the impacts of climate change on fisheries. Fish and fisheries, Vol. 10, no. 2: 173-196.

Anderson, L., 2016. MSC, Fisheries Improving Towards Marine Stewardship Council Certification. Available at: http://blog.msc.org/ blog/2016/02/08/improving-fips-towards-the-msc-standard/.

Barnes, R. A., 2012. Consolidating Governance Principles for Areas beyond National Jurisdiction. The International Journal of Marine and Coastal Law. 27, 2: 261-90.

Barnes, R., 2006. The Convention on the Law of the Sea: An Effective Framework for Domestic Fisheries Conservation? In: Freestone, D., Barnes, R. and Ong, D. eds. The law of the sea: progress and prospects. Oxford University Press.

Barnes, R., 2010. Fisheries and marine biodiversity. In: Fitzmaurice, M., Ong, D. and Merkouris, P. eds. Research handbook on international environmental law. Northampton: Edward Elgar Publishing. 
Bovens, M., 2007. Analysing and Assessing Accountability: A Conceptual framework. European Law Journal 13, 4: 447-68.

Bratspies, R., 2001. Finessing King Neptune: Fisheries Management and the Limits of International Law. Harvard Environmental Law Review. Vol. 25.

Bueger, C., 2015. What is maritime security? Marine Policy 53: 159-164.

Charnovitz, S., 2001. Rethinking WTO Trade Sanctions. The American Journal of International Law, Vol. 95, No. 4: 792-832.

Churchill R., 2012. The Persisting Problem of Non-Compliance with the Law of the Sea Convention: Disorder in the Oceans. International Journal of Marine and Coastal Law, Vol. 27, issue 4: 813.

Commission Decision on notifying the third countries that the Commission considers as possible of being identified as non-cooperating third countries pursuant to Council Regulation (EC) No. 1005/2008. Official Journal of the European Union. Vol. 55 of 17 November 2012.

Convention on International Trade in Endangered Species of Wild Fauna and Flora (CITES). 1973. 993 UNTS 243.

COUNCIL REGULATION (EC) No 1005/2008 of 29 September 2008 establishing a Community system to prevent, deter and eliminate illegal, unreported and unregulated fishing, amending Regulations (EEC) No 2847/93, (EC) No 1936/2001 and (EC) No 601/2004 and repealing Regulations (EC) No 1093/94 and (EC) No 1447/1999

Crawford, J., 2012. Brownlie's Principles of International Law. Oxford: 450

Daniels, A., Gutiérrez, M., Fanjul, C., Guereña, A., Matheson, A. and Watkins, K., 2016. Western Africa's Missing Fish: The Impacts of Illegal, Unreported and Unregulated Fishing and Under-Reported Catches by Foreign Fleets. Overseas Development Institute (ODI).

Dellinger, M., 2013. An Unstoppable Tide: Creating Environmental and Human Rights Law from the Bottom Up. Oregon Review of International Law 15.1: 63-140.

Dubnick, M. J., and Yang, K., 2009. The Pursuit of Accountability: Promise, Problems and Prospects. In Menzel, D. and White, H. eds. The State of Public Administration. New York: Armonk. 
Edeson, W., 2000. Tools to Address IUU Fishing: The Current Legal Situation. FAO Corporate Repository. Available at: http://www.fao.org/ docrep/005/y3274e/y3274e0a.htm.

Elferink, A. G. O., 2012. Governance Principles for Areas beyond National Jurisdiction. The International Journal of Marine and Coastal Law 27, 2: 205-59.

Environmental Justice Foundation (EJF). 2013. Sold to the Sea: Human Trafficking in Thailand's Fishing Industry. Available at: http:// ejfoundation.org/sites/default/files/public/Sold_to_the_Sea_ report_lo-res-v2.pdf

Erceg, D. 2006. Deterring IUU Fishing through State Control over Nationals. Marine Policy 30, 2: 173-79.

European Union Directorate of Maritime Affairs \& Fisheries, Infographic. Available at: http://ec.europa.eu/fisheries/documentation/publications/201504-tackling-iuu-fishing_en.pdf

Fact sheets of the European Union., 2015. Available at: http://www. europarl.europa.eu/ftu/pdf/en/FTU_5.3.6.pdf

FAO., 2001. International Plan of Action to Deter, Prevent and Eliminate Illegal, Unreported and Unregulated Fishing. IPOA IUU. Rome.

Flothmann, S., Kistowski, K., Dolan, E., Lee, E., Meere, F., and Album. G., 2010. Closing loopholes: getting illegal fishing under control. Science 328, no. 5983: 1235-1236.

Food and Agriculture Organization (FAO). 2014. State of the World's Fisheries and Aquaculture. Sofia.

Grant, R. W., and Keohane, R. O. 2005. Accountability and abuses of power in world politics. American Political Science Review, Vol. 99, No. 1: 29-43.

International Law Commission (ILC), Draft Articles on Responsibility of States for Internationally Wrongful Acts. 2011. Yearbook of the International Law Commission. Vol. II, Part 2.

Krisch, N. and Kingsbury, B., 2006. Introduction: Global Governance and Global Administrative Law in the International Legal Order. 
European Journal of International Law 17, 1:1-13.

Markowski, M., 2009. The International Legal Standard for sustainable EEZ Fisheries Management. In Winter G. ed. Towards sustainable fisheries Law: A Comparative Analysis. Bonn: IUCN.

Mashaw, J. L., 2006. Accountability and Institutional Design: Some Thoughts on the Grammar of Governance. Public Law Working Paper No. 116: 115-156.

Metuzals, K., Baird, R., Pitcher, T., Sumaila, U. R., Ganapathiraju, P., 2010. One fish, two fish, IUU and no fish: unreported fishing worldwide. In: Handbook of marine fisheries conservation and management. Oxford: Oxford University Press: 165-181

Miller, D. D., and Sumaila, U. R., 2014. Flag Use Behavior and IUU Activity within the International Fishing Fleet: Refining Definitions and Identifying Areas of Concern. Marine Policy 44: 204-11.

Molenaar, E. J. 2007. Current Legal and Institutional Issues Relating to the Conservation and Management of High Seas Deep-Sea Fisheries. Report and Documentation of the Expert Consultation on DeepSea Fisheries in the High Seas. FAO Fish. Rep 838: 113-39.

MSC, Fisheries Standards and Guidance, 2014 a. Available at: https://www. msc.org/documents/scheme-documents/fisheries-certificationscheme-documents/fisheries-standard-version-2.0.

MSC, Benchmarking and Tracking Tool (BMT). 2014 b. Available at: https:// www.msc.org/documents/developing-world/msc-accessibilitytools/msc-bmt-brochure.

Palma, M. A. E., Tsamenyi, M. and Edeson, W. R., 2010. Promoting sustainable fisheries: The international legal and policy framework to combat illegal, unreported and unregulated fishing. Brill.

Pauly, D. and Zeller, D., 2016. Catch reconstructions reveal that global marine fisheries catches are higher than reported and declining. Nature Communications 7.

Pitcher, T. J., Watson, R., Forrest, R., Valtýsson, H. and Guénette, S., 2002. Estimating Illegal and Unreported Catches from Marine Ecosystems: A Basis for Change. Fish and Fisheries. Vol. 3, no. 4: 317-39. 
Rached, D. H., 2016. The Concept(s) of Accountability: Form in Search of Substance. Leiden Journal of International Law. Vol. 29: 317-342.

Rayfuse, R., 2005. To Our Childrens's Children's Children: From Promoting to Achieving Compliance in High Seas Fisheries. The International Journal of Marine and Coastal Law. 20, 3: 509-32.

Request for an Advisory Opinion Submitted by the Sub-Regional Fisheries Commission (SRFC). 2014. ITLOS Reports.

Serdy, A., 2011. Postmodern International Fisheries Law, Or We Are All Coastal States Now. International \& Comparative Law Quarterly. 60, 02: 387-422.

Shaw, M., 2008. International Law. Cambridge University Press.

Standing, A., 2008. Corruption and industrial fishing in Africa. U4 Issue 7.

Stokke, O. S., 2009. Trade Measures and the Combat of IUU Fishing: Institutional Interplay and Effective Governance in the Northeast Atlantic. Marine Policy. Vol. 33, no. 2: 339-49.

Sundström, A., 2012. Corruption and regulatory compliance: Experimental findings from South African small-scale fisheries. Marine Policy. Vol. 36.6: $1255-1264$.

Takei, Y., 2013. Filling Regulatory Gaps in High Seas Fisheries: Discrete High Seas Fish Stocks, Deep-Sea Fisheries and Vulnerable Marine Ecosystems. Martinus Nijhoff Publishers.

Theilen, J. T., 2013. What's in a Name? The Illegality of Illegal, Unreported and Unregulated Fishing. The International Journal of Marine and Coastal Law. Vol. 28, No. 3: 533-50.

Tzevelekos, V. P., 2010. In Search of Alternative Solutions: Can the State of Origin Be Held Internationally Responsible for Investors' Human Rights Abuses that Are Not Attributable to It? Brooklyn Journal of International Law. Vol. 35: 155-231.

UN General Assembly. 2008. Resolution 63/112.

UN General Assembly. 2012. The Future We Want. A/Res/66/288.

UN General Assembly. 2015. Transforming our World: The 2030 Agenda for Sustainable Development. A/Res/70/1. 
(U) United Nations Convention on the Law of the Sea (LOSC). 1982. 1833 UNTS 3.

UNODC. 2011. Transnational Organized Crime in the Fishing Industry. Available at: http://www.unodc.org/documents/human-trafficking/ Issue_Paper_-_TOC_in_the_Fishing_Industry.pdf

Warner-Kramer, D., 2004. Control Begins at Home: Tackling Flags of Convenience and IUU Fishing. Golden Gate University Law Review 34.

Mercedes Rosello is an international and European fisheries law, policy and governance researcher and a PhD candidate at the University of Hull. Mercedes is the editor of the IUU Fishing Blog, which can be accessed through www.houseofocean. org. She is registered with the Law Society of England \& Wales as a non-practising Solicitor. 